\title{
Kestane/Gürgen Talaşı Dolgulu Vinilester Kompozitlerin Mekanik Özelliklerinin İncelenmesi
}

\author{
İlyas Kartal ${ }^{1 *}$, Gülşah Nayc1 $^{2}$, Halil Demirer ${ }^{3}$ \\ ${ }^{1}$ Marmara Üniversitesi, Teknoloji Fakültesi, Metalurji ve Malzeme Mühendisliği Bölümü, İstanbul, Türkiye (ORCID: 0000-0001-9677-477X) \\ ${ }^{2}$ Marmara Üniversitesi, Fen Bilimleri Enstitüsü, Metalurji ve Malzeme Mühendisliği Anabilimdalı, İstanbul, Türkiye (ORCID: 0000-0001-7628-2524) \\ ${ }^{3}$ Marmara Üniversitesi, Teknoloji Fakültesi, Metalurji ve Malzeme Mühendisliği Bölümü, İstanbul, Türkiye (ORCID: 0000-0001-7870-5797)
}

(İlk Geliş Tarihi 17 Mayıs 2019 ve Kabul Tarihi 22 Temmuz 2019)

(DOI: 10.31590/ejosat.566756)

ATIF/REFERENCE: Kartal, İ., Naycı, G. \& Demirer, H. (2019). Kestane/Gürgen Talaşı Dolgulu Vinilester Kompozitlerin Mekanik Özelliklerinin İncelenmesi. Avrupa Bilim ve Teknoloji Dergisi, (16), 723-728.

\section{$\ddot{O} \mathbf{z}$}

Petrol esaslı geleneksel kompozitler toksiktirler ve biyolojik olarak parçalanamazlar; geri dönüştürülmeleri zor ve pahalıdır. Bu sebeple günümüzde çevresel kaygılar, artan atık problemleri, azalan doğal kaynaklar gibi önemli problemlere olası çözümler bulması için bileşenleri yenilenebilir kaynaklardan gelen kompozit (yeşil kompozit) üretimi teşvik edilmektedir. Bu çalışmada $150 \mu \mathrm{m}$ boyutundaki atık kestane ve gürgen talaşları vinilester matriste dolgu olarak kullanılmıştır. Çalışmada, kestane talaş1-vinilester, gürgen talaşıvinilester, kestane+gürgen talaşı-vinilester kombinasyonları hazırlanmıştır. Her bir kombinasyon ağaç talaşı/reçine ağırlık oranı \%5, $\% 10, \% 15, \% 20$ olacak şekilde 4 oranda hazırlanmış, çalışmada toplam 12 farklı kompozit numunesi kullanılmıştır. Çalışmada kestane ve gürgen talaşlarının kompozitte dolgu olarak kullanımının incelenmesinin yanı sıra dolgu oranı etkisi de incelenmiştir. Numunelerin çekme, 3 nokta eğme, darbe ve sertlik gibi mekanik özellikleri incelenmiş ve test sonuçları grafiklerle yorumlanmıştır. Numunelerin SEM görüntüleri incelenmiştir. Vinilester içinde dolgu oranı artmasıyla mekanik özelliklerinde kısmi iyileşme gözlemlendi. Kestane ile gürgen talaşları kıyaslandığında aralarında büyük bir fark olmamasına karşın kestane dolgulu kompozitlerin mekanik özellikleri daha yüksek olduğu, ideal dolgu oranının ise \%10 olduğu değerlendirilmiştir.

Anahtar Kelimeler: Yeşil kompozitler, Vinilester reçinesi, Kestane Talaşı, Gürgen Talaşı.

\section{Investigation of the Mechanical Properties of Chestnut/Hornbeam Sawdust Filled Vinyl Ester Composites}

\begin{abstract}
Petroleum-based conventional composites are toxic and not biodegradable; they are difficult to recycle and expensive. Nowadays, composite (green composite) production from renewable sources is encouraged to find possible solutions to important problems such as environmental concerns, increased waste problems, and reduced natural resources. In this study, $150 \mu \mathrm{m}$ waste chestnut and hornbeam wood sawdust were used as filler in vinylester matrix. In this study, chestnut sawdust-vinylester, chestnut sawdust-vinylester, chestnut + hornbeam sawdust-vinylester combinations were prepared. Each combination of wood sawdust/resin weight ratio of 5\%, 10\%, 15\%, $20 \%$ was prepared in 4 proportions, a total of 12 different composite samples were used in the study. In this study, the use of chestnut and hornbeam sawdust as fillers in the composite was examined as well as the fill rate effect. Mechanical properties such as tensile, 3 point bending, impact and hardness of the samples were examined and test results were interpreted with graphics. SEM images of the samples were examined. Improvement in mechanical properties was observed with increasing filler ratio in vinyl ester. Compared to
\end{abstract}

\footnotetext{
* Sorumlu Yazar: Marmara Üniversitesi, Teknoloji Fakültesi, Metalurji ve Malzeme Mühendisliği Bölümü, İstanbul, Türkiye, ORCID: 0000-00019677-477X, ilyaskartal@marmara.edu.tr
} 
chestnut and hornbeam chips, there was no significant difference, but it was found that chestnut filled composites had higher mechanical properties and an ideal fill rate of $10 \%$.

Keywords: Green composites, Vinylester resin, Chestnut Sawdust, Hornbeam Sawdust.

\section{Giriş}

İnsanoğlunun artan ihtiyaçları, mühendislik alanında her geçen gün yeni çalışmalar doğurmaktadır. Tek bileşenle erişilemeyen özelliklere sahip bir malzeme üretmek için birkaç bileşeni birleştirme fikri ise bu ihtiyaçlara cevap vermekte önemli bir rol oynamaktadır. Dolayısıyla günümüzde yapılan mühendislik çalışmalarının kayda değer kısmı kompozit malzemeler üzerinedir (Vasiliev ve ark 2013).

Kompozitler, iki ya da daha fazla malzemenin uygun özelliklerini tek bir malzemede toplamak ve daha üstün yeni özellikler elde etmek için birden fazla malzeme veya fazın uygun bir yöntemle birleştirilmesi sonucu elde edilen malzemelerdir. Farklı durumlara uyarlanabilme, spesifik amaçlara hizmet etme, arzu edilen özellikleri sergileme, kimyasallara ve korozyona karşı dayanıklılık, yüksek dayanıklılık/yoğunluk oranı, yüksek modül/ağırlık oranı, hafiflik gibi olumlu özellikleriyle oldukça sık tercih edilen bir malzeme sınıfıdır. Havacılık, uzay ve savunma sanayi, kara ve deniz taşıtları, spor malzemeleri, inşaat, alt yapı ve enerji sektörü gibi çok geniş ve çeşitli alanlarda kullanılmaktadır (Jose ve ark. 2012, Sabu ve ark. 2012, Kandpal ve ark. 2015).

Fakat tüm bu avantajlara rağmen petrol esaslı geleneksel kompozitler toksiktirler ve biyolojik olarak parçalanamazlar. Kullanım ömrünü tamamlamış geleneksel kompozit malzemelerin geri dönüştürülmeleri zor ve pahalıdır, bazen gömülerek bazen de yakılarak imha edilirler. İmha edilen malzemelerin oluşturduğu kirlilik ve hızla azalmakta olan doğal kaynaklar ise gelecek için büyük sorun oluşturmaktadır. Bu sebeple son yıllarda çevresel endişeler ve yasal mercilerin talepleriyle birlikte; çevre dostu, sürdürülebilir hammaddelere olan ilgi de artmıştır. Mühendislik uygulamalarındaki kompozitlerde takviye malzemesi olarak doğal liflerin, dolgu malzemesi olarak ise odun materyallerinin kullanımı giderek yaygınlaşmış, yeşil kompozitler kavramı önem kazanmaya başlamıştır (Santulli ve ark. 2013, Yan ve ark. 2014).

Yeşil kompozitler, bileşenlerden en az birinin, doğal kaynaklardan elde edildiği özel bir kompozit sınıfıdır. Biyolojik olarak parçalanabilme, çevresel problemlere ve azalan kaynaklara çözüm bulma, kolay işlenebilme, cildi tahriş etmeme, uygun maliyet, esneklik artışı, ses yalıtımı, geri dönüşüm gibi olumlu özellikleri geleneksel kompozitlere alternatifler sunmaktadır. Doğal liflerden ve biyolojik olarak parçalanabilir polimerlerden meydana gelmesi sebebiyle 21. yüzyılda çevre sorununa önemli bir katkı sağlayacağı ve azalan petrol kaynakları için de umut verici bir potansiyel olacağı düşünülmektedir.

Tüm bu olumlu özelliklerle, yeni çevre dostu polimerik kompozit malzeme olarak ortaya çıkan yeşil kompozitler, ticari ve mühendislik uygulamalarında tekno-ekonomik avantajlar sunmakta ve global pazardan çok yüksek bir baskıya sahip olmaktadır. Bu sebeple günümüzde, bilim insanları ve araştırmacılar için, mevcut pazarda bulunan çeşitli polimerlerin özelliklerini ve uygunluğunu, yeşil kompozit için matris malzemesi olarak kullanılıp kullanılmayacaklarını araştırmak gittikçe önem kazanmaktadır (Thakur ve ark. 2014, Paul ve ark. 2003).

Bu çalışmada da matris malzemesi olarak vinilester polimeri, doğal dolgu olarak ise kestane ve gürgen talaşları kullanılarak bir yeşil kompozit üretimi yapılmıştır.

Vinilester reçineleri, epoksi ile doymamış asitin reaksiyona girmesiyle elde edilmektedir. Stiren monomerinde çözünmüş metakrilik asit ve bisfenol A (BPA) epoksi reçinesinin reaksiyonu en yaygın versiyonudur. Çevre koşullarına dayanıklılığı ile bilinir çünkü yüksek reaktiviteleri tam kürlenmeye polyesterlerden daha kolay ve daha hızlı ulaşmaktadır. Vinilester reçineler, epoksi reçinelerin avantajları ile doymamış polyester reçinelere özgü kolay işleme/hızlı sertleşme gibi özellikleri birleştirmek üzere geliştirilmiştir. Aynı zamanda mekanik dayanım ve mükemmel korozyon dayanımı sağlamaktadır. Bu üstün özellikleri sayesinde epoksi reçinelerdeki gibi karmaşık proses veya özel kullanım becerisi gerektirmezler. Bu sebeple çalışmamızda matris malzemesi olarak vinilester reçinesi seçilmiştir (Blankenship ve ark. 1989, Astrom 1997).

Literatürde doğal dolgu ile takviyelendirilmiş pek çok yeşil kompozit çalışması mevcuttur.

Johnson ve ark. tarafindan yapılan çalışmada plastik kompozitlerde güçlendirici dolgu maddesi olarak buğday sapının ticari olarak kullanılabilirliği araştırılmıştır. Buğday sapı ilavesiyle, kompozitlerin çekme direncinin \%3“den \%162'ya kadar, eğilme direncinin $\% 13^{\text {ee }}$ den $\% 48^{\text {ee }}$ kadar arttığı, \%30 buğday sapı kompozitlerinde çekme-elastikiyet modülü değerlerinin iki kat daha yüksek olduğu bulunmuştur (Johnson ve ark. 1997). Bir başka çalışmada Ajiwe ve ark. pirinç kabuğu ve talaşı gibi tarımsal atıklardan taban döşemeleri için levhalar üretilmiş, yapılan testler sonucunda üretilen levhaların ticari olarak mevcut levhalara benzer standartlarda olduğunu rapor etmişlerdir (Ajiwe ve ark. 1998). Panthapulakkal ve ark. eski gazete kâğıdı, odun talaşı ve tarımsal atıklar ile hazırlanan kompozitlerin mekanik özellikleri incelenmiş, termoplastikler için alternatif dolgu maddesi olarak tarımsal atıkların uygun olduğunu rapor etmişlerdir (Panthapulakkal ve ark. 2006). Kurt ve Mengeloğlu ise yakılarak kullanılan orman endüstri atığının ve tarımsal atıkların, un haline getirilerek ya da liflendirilerek termoplastiklerle karıştırılması sonucunda maliyeti ve son ürünün özelliklerini iyileştirdiğini belirtmiş, bu atıkların odun-plastik kompozit üretiminde dolgu maddesi olarak kullanılmasını önermişlerdir (Kurt ve ark. 2006). 


\section{Materyal ve Metot}

\subsection{Malzemeler}

Bu çalışmada doğal dolgu malzemesi olarak; $150 \mu \mathrm{m}$ 'lik elekten geçirilmiş 0-150 $\mu \mathrm{m}$ boyutunda atık kestane ve gürgen talaşları kullanılmıştır. Matris malzemesi olarak ise el yatırma yöntemi için en ideal olan Bisphenol-A epoksi esaslı vinilester reçinesi (E275Erco Boya, İstanbul) seçilmiştir. Reaksiyon başlatıcı olarak ise \%50 aktif metil etil keton peroksit (Erco Boya, İstanbul) kullanılmıştır. Hızlandırıcı olarak kullanılan kobalt naftalat reçine bünyesinde bulunduğu için haricen kullanılmamıştır. Ayrıca standart çekme, üç nokta eğme, darbe ve sertlik numunelerini hazırlamak için Teflon kalıp kullanılmıştır.

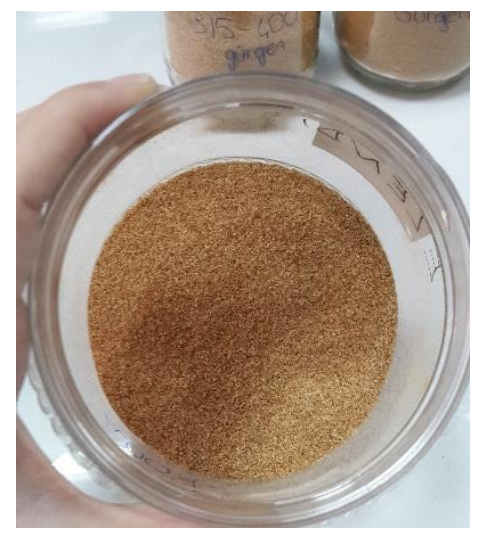

(a)

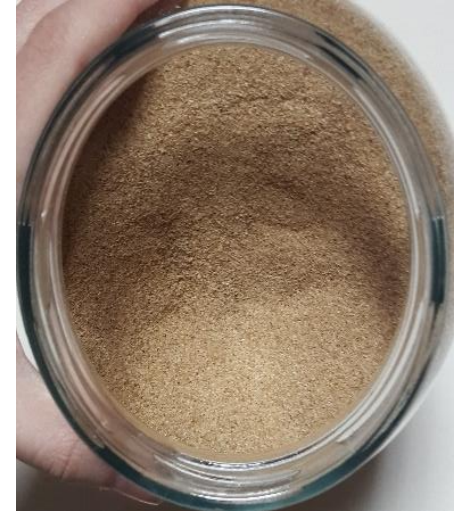

(b)

Şekil 1. Çalışmada Kullanılan Gürgen (a) ve Kestane (b) Talaşları

\subsubsection{Numunelerin Hazırlanmast}

Kestane ve gürgen ağacı talaşları, deneyde kullanılmadan kurumaları için etüvde bir süre bekletilmiş, daha sonra çalışmada kullanılmıştır. Kurutulan talaşlar elekten geçirilerek $150 \mu \mathrm{m}$ boyutunda talaşlar elde edilmiştir. Çalışmada üretilen kompozitler; kestane talaş1-vinilester, gürgen talaş1-vinilester, kestane+gürgen talaşı-vinilester kombinasyonlarındadır. Her bir kombinasyon talaş/reçine ağılık oranı $\% 5, \% 10, \% 15, \% 20$ olacak şekilde 4 oranda üretilmiş, çalışmada toplam 12 farklı kompozit çeşidi kullanılmıştır. Talaşlar $\% 5,10,15$ ve 20 oranlarıyla vinilester reçineye ilave edilmiş, homojen bir hal alması için bir süre karıştırma işlemi uygulanmıştır. Reçinenin sertleşebilmesi için \%2 oranında metil etil keton peroksit sertleştirici ilave edilmiştir. Hazırlanan karışım, düzgün bir yüzey üzerindeki Teflon kalıba dökülmüştür. Kür uygulaması için numuneler oda sıcaklığında 16 saat boyunca bekletildikten sonra kalıptan çıkarılmıştır.

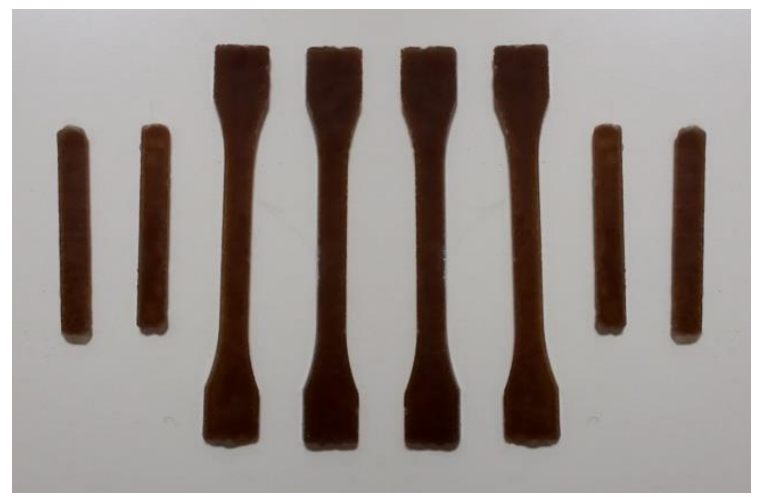

Şekil 2. Teflon kaliptaki numuneler

ISO 527 standardına göre hazırlanan numunelerin çekme deneyi, Zwick Z010 üniversal çekme cihazında 5 mm/dakika çekme hızı ile yapılmıştır. ISO 179 standardına göre hazırlanan numunelerin üç nokta eğme testi de Zwick Z010 model cihaz da 5 mm/dakika hızla yapılmıştır. ISO 180 standardına göre hazırlanan çentiksiz numunelerin darbe mukavemeti, Zwick B5113.30 darbe cihazında 5,4 J'lük Izod çekici kullanılarak test edilmiştir. Sertlik ölçümleri Zwick Shore D cihazında, 15 sn. süre beklenilerek yapılmıştır. Yapılan testlerde her bir grup için 5 numune hazırlanmış olup ortaya çıkan değerlerin ortalaması alınmıştır. 


\section{Araştırma Sonuçları ve Tartışma}

Bu çalışmada kestane ve gürgen talaşlarının kompozitte dolgu olarak kullanımının incelenmesinin yanı sıra dolgu oranı etkisi de incelenmiş̧ir. Bunun için numuneler çekme, 3 nokta eğme, darbe ve sertlik testlerine tabi tutulmuiş mekanik özellikleri ve SEM görüntüleri incelenmiştir.

Çekme mukavemetinin talaş türüne ve oranına göre değiş̧imi şekil 3’te verilmiştir. Kompozitler arasında en yüksek çekme mukavemetine kestane talaşı dolgulu vinilester kompozitleri ulaşmıştır. Kestane talaşı dolgulu kompozitlerde en yüksek çekme mukavemeti değerine ise \%10 oranında ulaşılmıştır. En düşük çekme muvametine sahip olan kompozit ise dolgu/reçine ağırlı oranı $\% 20$ olan gürgen talaşı dolgulu vinilester kompozitidir. Yine bu sonuca göre, kompozitlerin genelinde talaş ağırlık oranının artmasıyla çekme mukavemetinde bir azalma meydana geldiği de görülmektedir.

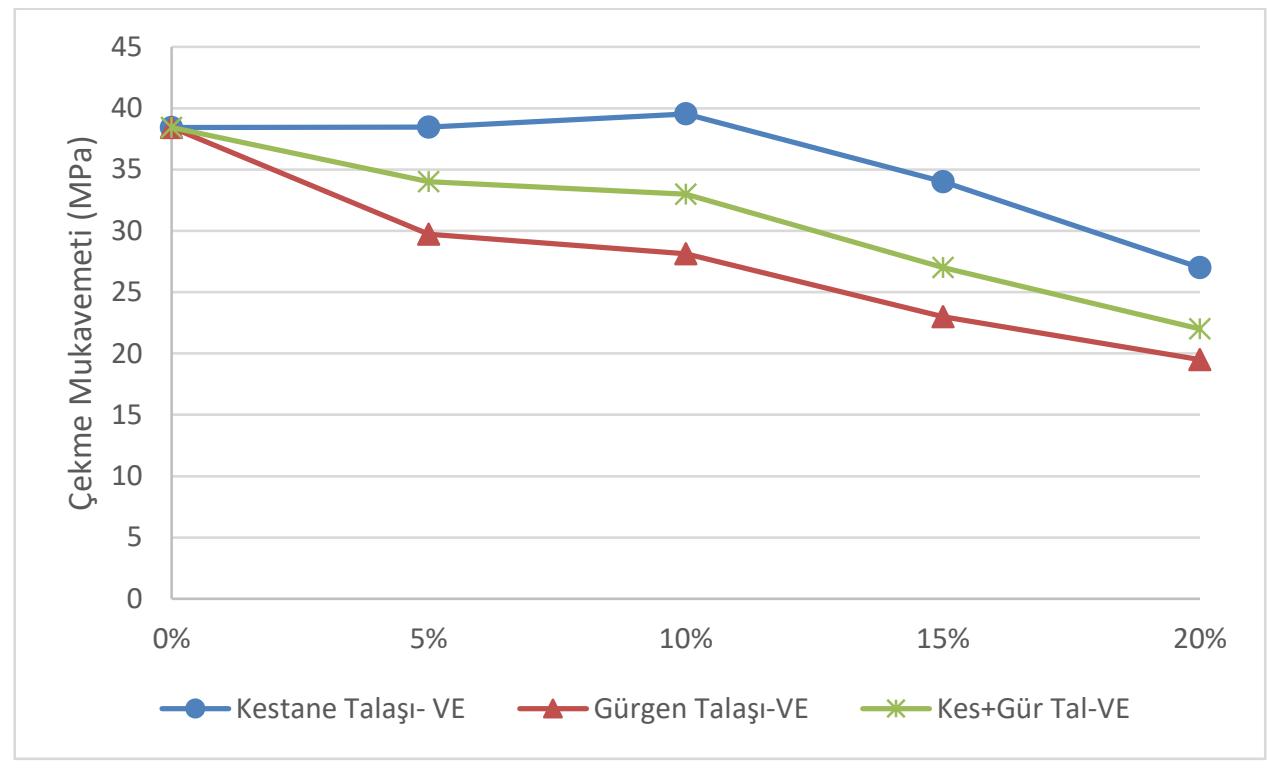

Şekil 3. Çekme Mukavemetinin Talaş Türüne ve Oranına Göre Değişimi

Üç nokta eğilme mukavemetinin talaş türüne ve oranına göre değişimi şekil 4'te verilmiştir. Eğilme mukavemetleri karşılaştırıldığında en yüksek eğilme mukavemetine kestane talaşı dolgulu vinilester kompozitinin (\%10) ulaştığ görülmektedir. Gürgen talaşı vinilester kompoziti (\%20) en düşük eğilme mukavemetine sahiptir.

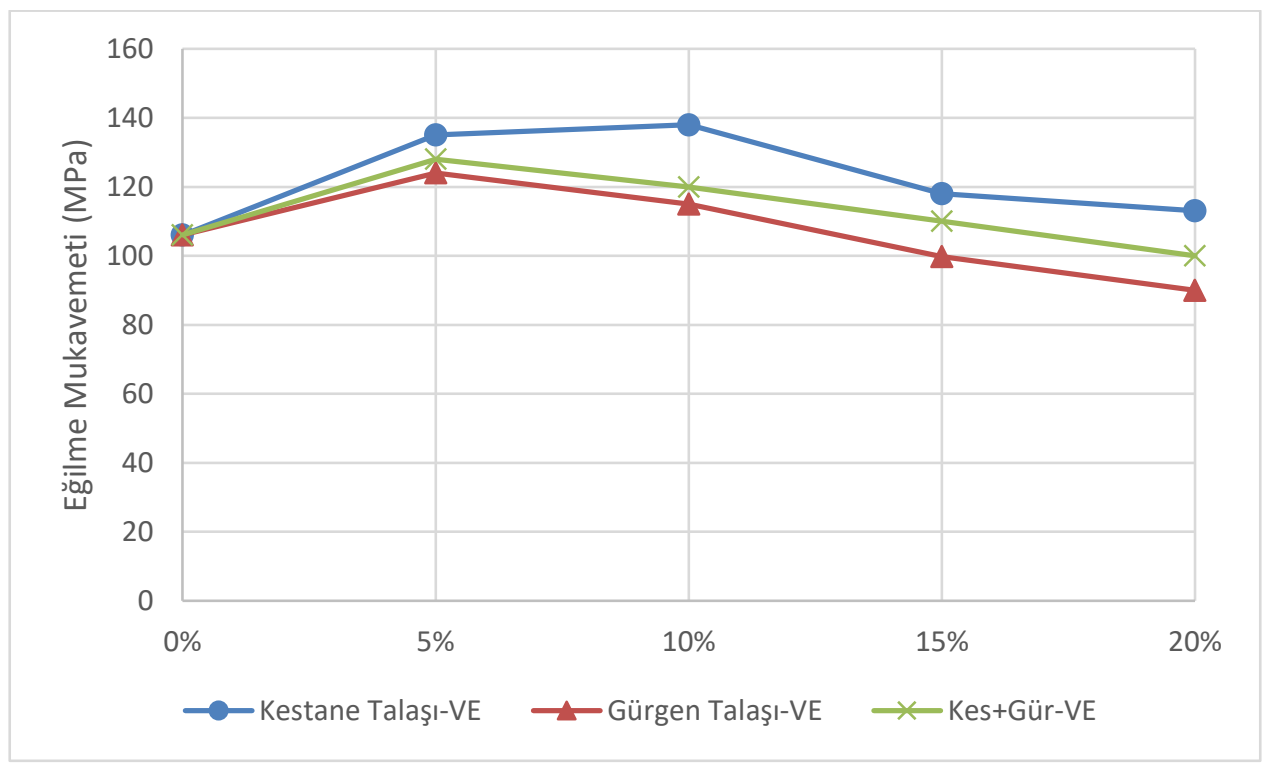

Şekil 4. Eğilme Mukavemetinin Talaş Türüne ve Oranına Göre Değişimi 
Izod darbe dayanımının talaş türüne ve oranına göre değişimi şekil 5 'te verilmiştir. Talaş ilavesi ile darbe direncinde azalma meydana gelmiştir. En yüksek darbe mukavemetine sahip kompozit kestane talaş1-vinil ester kompozitidir (\%5).

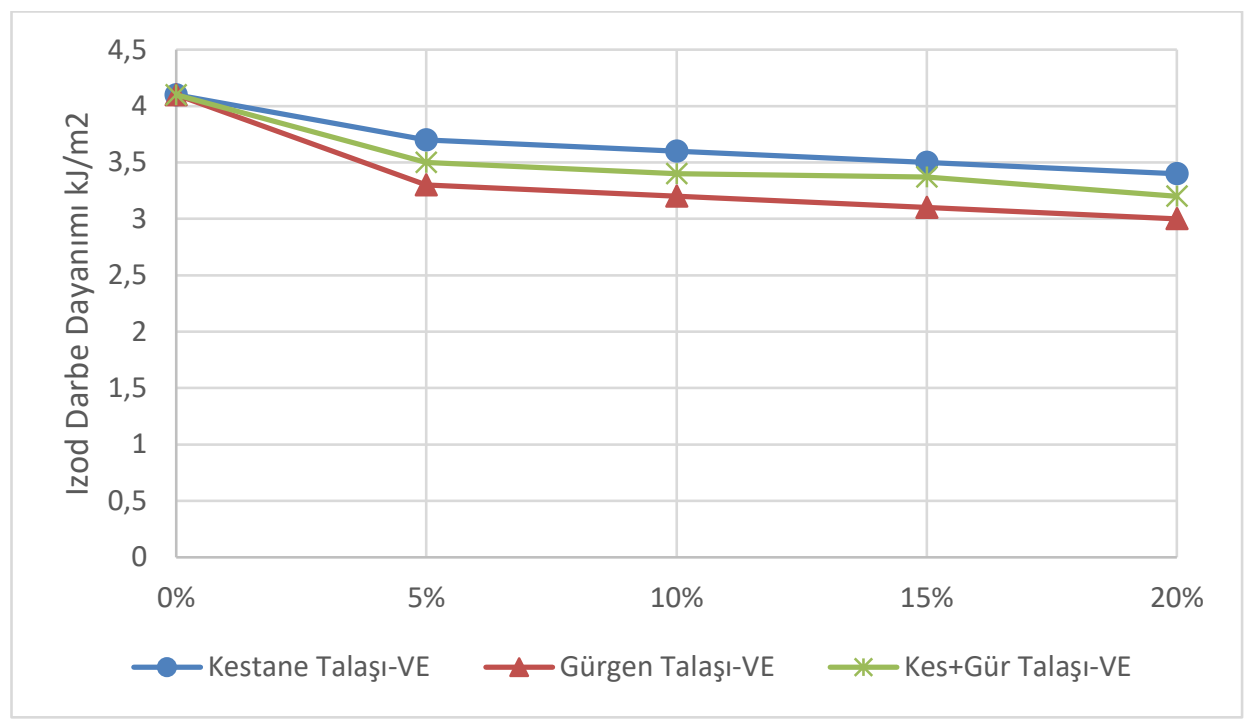

Şekil 5. Izod Darbe Dayanımının Talaş Türüne ve Oranına Göre Değişimi

Shore D sertlik değerinin lif türüne ve oranına göre değişimi şekil 6'da verilmiştir. Ağaç talaşı ilavesi ile sertlik değerlerinde artı̧̧ meydana geldiği gözlenmiş̧tir. Grafiğe göre en yüksek sertlik değerine sahip kompozit, kestane talaşı dolgulu vinilester kompozitidir. \%5 oranı sonrası genel olarak sertlik değerlerinde düşme görülmektedir. Sertlik testini; talaş oranı miktarının artmasıyla gözenek oluşumunun artması, karışalabirlik ve akışkanlığın azalması, dökümün zorlaşması gibi faktörler etkilemiştir. Talaş oranı arttıkça sertlik değerlerinde azalma meydana gelmesi de bu sebeplere bağlanmaktadır.

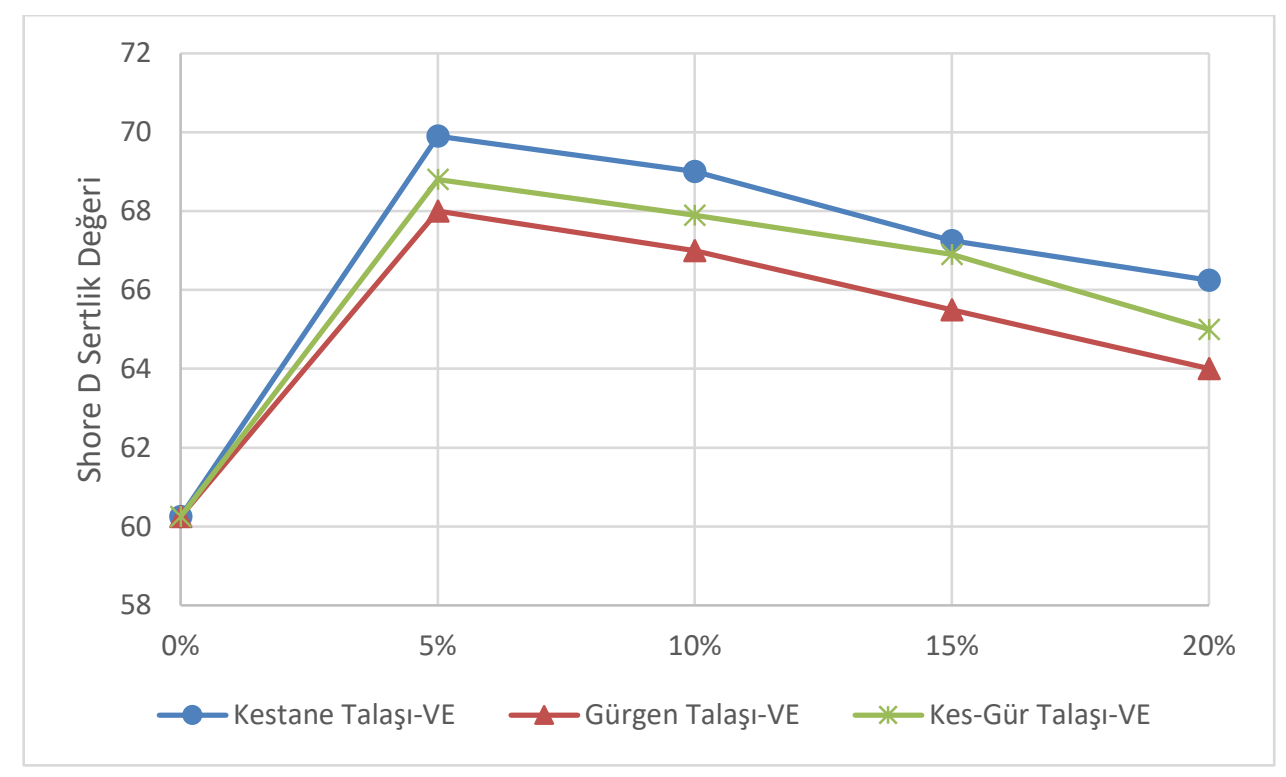

Şekil 5. Shore D Sertlik Değerinin Talaş Türüne ve Oranına Göre Değişimi 


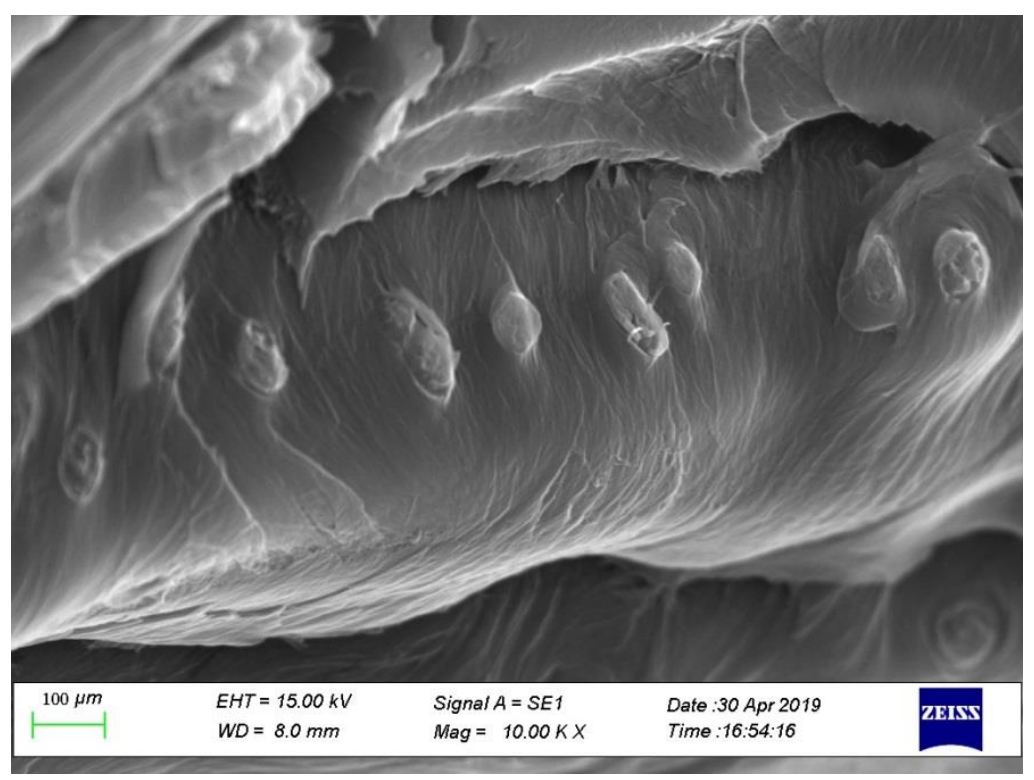

Şekil 6. Kompozite Ait Tipik Bir SEM Görüntüsü

\section{Sonuç}

$\mathrm{Bu}$ çalışmada kestane ve gürgen talaşlarının kompozitte dolgu olarak kullanımı incelenmiştir. Vinilester kompozitte dolgu oranı artmasıyla bir miktar mekanik özelliklerinde iyileşme gözlemlenmiştir. \%10 oranında bir kestane veya gürgen dolgusunun kullanılabilir olduğu değerlendirilmiştir. Yine kestane ile gürgen talaşları kıyaslandığında aralarında bariz bir fark olmamasına karşın kestane dolgulu kompozitlerin mekanik özellikleri daha yüksek tespit edilmiştir. Özellikle tarım ve el aletleri yapımında tercih edilmiş/edilen kestane ağacının iyi mekanik özelliklere sahip olmasının kompozitin mekanik özelliklerine yansıdığı belirlenmiştir. Bu çalışma neticesinde özellikle kestane ağacı talaşının kompozit uygulamalarında dolgu olarak kullanılabileceği değerlendirilmiştir.

\section{Teşekkür}

Bu çalışma Marmara Üniversitesi Bilimsel Araştırma Projeleri Komisyon Başkanlığı tarafından FEN-C-YLP-121218-0623 (2019) nolu proje kapsamında desteklenmiştir.

\section{Kaynakça}

Valery V., Evgeny M. (2013). Advanced Mechanics of Composite Materials and Structural Elements (third edition): Elsevier.

Jose A.M., Kim Y.A., Leal-Ekman S., Hunter C.P. (2012). Conserved tyrosine kinase promotes the import of silencing RNA into Caenorhabditis elegans cells, Proc. Natl. Acad. Sci. USA., 109: 14520-14525.

Sabu, T., Kuruvilla J.; Kumar, M., Goda, K., Sreekala M. S. (2012). Introduction to Polymer Composites, Polymer Composites, Volume 1, First Edition, Wiley-VCH Verlag GmbH \& Co 209.

Kandpal, B.C., Chaurasia, R., Khurana, V. (2015). Recent Advances in Green Composites - A Review, International Journal For Technological Research In Engineering (IJTRE) vol. 2, Issue 7, March. 2015.

Santulli, C., Sarasini, F., Tirillò, J., Valente, T., Valente, M., Caruso, A.P., Infantino, M., Nisini, E., Minak, G. (2013). Mechanical Behaviour of Jute Cloth/Wool Felts Hybrid Laminates, Materials and Design, vol. 50, pp. 309-321.

Yan, L., Chouw, N., Jayaraman, K. (2014). Flax Fibre and Its Composites, Composites: Part B Engineering (Compos Part B- Eng), vol. 56, pp. 296-317.

[Thakur, V. K., Thakur, M.K., Gupta, R.K. (2014). Review: Raw Natural Fiber-Based Polymer Composites, International Journal of Polymer Anal. Charact. (IJPAC), vol. 19, pp. 256-271.

Paul, W., Jan, I., Ignaas, V. (2003). Natural Fibers: Can They Replace Glass in Fiber Reinforced Plastics, Comput Sci Technol, vol. 63, pp.1259-1264.

Blankenship, L.T., White, M.N., Puckett, P.M. (1989). Vinyl Ester Resins: For Composites, Dow Chemical U.S.A, Freeport, Texas, pp. $1-36$.

Panthapulakkal, S., Sain, M. (2006). Injection molded wheat straw and corn stem filled polypropylene composites, Journal of Polymers and the Environment, 14:265-272.

Astrom, B.T. (1997). Manufacturing of Polymer Composites, Department of Aeronautics, Royal Insitute of Technology, Chapman \& Hall, pp. 1-175. 